\title{
PERANCANGAN E-REMINDER AKTIFITAS MAHASISWA PADA FAKULTAS TEKNIK UNIVERSITAS BHAYANGKARA JAKARTA RAYA
}

\author{
Dwi Swasono Rachmad ${ }^{1)}$ Gabriel Firsta Adnyana ${ }^{2)}$ \\ Jurusan Teknik Informatika, Fakultas Teknik, \\ Universitas Bhayangkara ${ }^{(1)}$ \\ Program Studi Teknik Informatika, Fakultas Ilmu Kesehatan Sains dan Teknologi, \\ Universitas Dhayana Pura ${ }^{(2)}$ \\ dwi.swasono@dsn.ubharajaya.ac.id ${ }^{1)}$ Gabrieladnyana89@undhirabali.ac.id ${ }^{(2)}$
}

\begin{abstract}
One of strategic that has been carried out by several universities in Indonesia to achieve quality academic and governance services is through the use of Information and Communication Technology (ICT) in the form of the use of academic information systems that contribute to improving the reputation of universities, as well as increasing user satisfaction. Lecture activities such as teaching and learning activities (KBM), the implementation of the semester exam, lecturer meeting is a daily operational activities. Teaching and learning activities are things that have become routine, but still often happens that students forget the academic activities that become obligations either because of a schedule change or other reasons. Regular schedule changes are usually distributed by the Administration to students or lecturers manually through a notice board The use of media boards raises difficulties for students, especially for students who have off-campus activities so the use of bulletin boards to convey information about lectures and academic activities among students became less effective. Therefore, an application is needed to help the delivery of information in realtime to remind students to carry out academic activities on schedule. Target to be achieved is to provide an e-reminder application of academic activities. This application consists of 3 users, the admin to enter the information mading, user (lecturer) to determine the schedule of guidance and user (student) to display the schedule of lectures, and the payment of the lecture along with notification of the schedule reminder so it can help and provide convenience for the administration in preparing and reminding activities to be carried out so that students can see about academic information and tuition payment information in real time both to students who are inside and outside the campus.
\end{abstract}

Keywords : e-reminder, academic activities, mobile app

Beberapa perguruan tinggi di Indonesia untuk mencapai pelayanan akademik dan tata kelola yang berkualitas adalah melalui pemanfaatan Teknologi Informasi dan Komunikasi (TIK) berupa penggunaan sistem informasi akademik yang berperan untuk meningkatkan reputasi perguruan tinggi, serta meningkatkan kepuasan pengguna Kegiatan belajar mengajar merupakan hal yang sudah menjadi rutinitas, namun masih seringkali terjadi mahasiswa yang lupa dengan aktifitas akademik yang menjadi kewajibannya karena adanya perubahan jadwal, ataupun hal lainnya. Perubahan jadwal regular biasanya didistribusikan oleh pihak Tata Usaha ke mahasiswa atau dosen secara manual melalui papan pengumuman. Penggunaan media papan pengumuman menimbulkan kesulitan bagi mahasiswa, terutama bagi mahasiswa yang mempunyai aktifitas di luar kampus sehingga penggunaan papan pengumuman untuk menyampaikan seputar informasi perkuliahan dan kegiatan akademik di kalangan mahasiswa menjadi kurang efektif. Aplikasi ini terdiri dari 3 pengguna, yaitu admin untuk memasukan informasi mading, user (dosen) untuk menentukan jadwal bimbingan dan user (mahasiswa) untuk menampilkan jadwal kuliah, dan pembayaran kuliah beserta notifikasi pengingat jadwal tersebut sehingga dapat membantu dan memberikan kemudahan bagi pihak tata usaha dalam menyusun serta mengingatkan kegiatan yang akan dilakukan sehingga mahasiswa dapat melihat seputar informasi akademik dan informasi pembayaran uang kuliah secara real time baik kepada mahasiswa yang berada didalam maupun diluar kampus.

Kata kunci : e-reminder, aktifitas akademik, aplikasi mobile 


\section{PENDAHULUAN}

Perkembangan teknologi informasi memberikan pengaruh yang sangat besar di dalam kehidupan sehari-hari di sekitar kita, contohnya dalam bentuk kalender. Kalender yang ada saat ini bermacam-macam jenisnya, dicetak seperti kalender dinding dan kalender meja, dan ada pula yang berbentuk digital seperti yang terdapat di ponsel. Penggunaan kalender di ponsel lebih banyak digunakan saat ini dikarenakan bisa langsung diseleraskan dengan reminder dan alarm di ponsel. Berbeda dengan kalender cetak karena kita harus sesekali melihat ke kalender jikalau ada janji sehingga terlewat.

Kehadiran smartphone sebagai salah satu produk teknologi terbaru di bidang selular diharapkan membantu mahasiswa mengakses informasi jadwal dengan efektif dan efisien. Kemampuan smartphone untuk selalu terkoneksi dengan internet dapat membantu mahasiswa memantau jadwal kuliah secara real-time. Fitur notifikasi yang dimiliki smartphone yang mudah dibawa dapat mengakses informasi jadwal dimana saja.

Kegiatan perkuliahan seperti Kegiatan Belajar Mengajar (KBM), pelaksanaan ujian semester, rapat dosen merupakan kegiatan operasional sehari-hari. Meskipun KBM merupakan hal yang sudah menjadi rutinitas, namun masih seringkali terjadi mahasiswa maupun dosen lupa dengan jadwal kegiatan perkuliahan yang menjadi kewajibannya, entah karena adanya perubahan jadwal dari jadwal reguler ataupun alasanya lainnya sehingga menimbulkan adanya keterlambatan yang seringkali mengganggu aktivitas.

Penggunaan papan pengumuman memiliki kelebihan dapat menampilkan jumlah informasi jadwal yang lengkap. Sebuah informasi yang terdapat pada papan pengumpulan dapat diakses oleh mahasiswa dengan cara mendatangi kampus dan melihat informasi tersebut secara langsung. Metode mengakses informasi tersebut secara langsung menimbulkan kesulitan bagi mahasiswa, terutama bagi mahasiswa yang mempunyai aktifitas lain diluar kampus.

Untuk menunjang tuntutan dari kebutuhan tersebut, maka sebuah perguruan tinggi membutuhkan sebuah aplikasi pengingat yang akurat, efisien dan bersifat portable. Pada kenyataannya, hal ini terkadang tidak sesuai dengan keinginan karena kurang dan terbatasnya sarana pengingat yang digunakan selama ini. Dalam hal ini untuk pengingat hanya merupakan kesadaran individual saja tidak terintegrasi.

Universitas Bhayangkara Jakarta Raya adalah salah satu kampus yang ada di Bekasi. Sebagai salah satu kampus swasta Universitas Bhayangkara Jakarta Raya harus bisa menyampaikan informasi yang jelas, detail dan menyeluruh tentang kegiatan akademik khususnya tentang jadwal perkuliahan, pembayaran dan informasi penting lainnya. Dalam memberikan informasi Universitas Bhayangkara Jakarta Raya kepada mahasiswa masih menggunakan papan pengumuman sebagai penyajian tentang informasi-informasi terkait kegiatan akademik maupun info kalender akademik salah satunya pembayaran kuliah. Universitas Bhayangkara Jakarta Raya dimana terbagi dalam 5 jurusan yaitu Teknik Informatika, Teknik Industri, Teknik Kimia, Teknik Lingkungan dan Teknik Perminyakan. Dengan melonjaknya jumlah mahasiswa, sering terjadi kelalaian dalam penyampaian informasi mengenai aktifitas akademik yang menyebabkan banyak mahasiswa yang tidak menghadiri kegiatan akademik tersebut.

Penulis kemudian membuat kuesioner untuk dibagikan kepada 200 mahasiswa Fakultas Teknik Universitas Bhayangkara Jakarta Raya, dengan salah satu pertanyaannya yaitu "Menurut pendapat anda, apakah mahasiswa selalu mengingat jadwal perkuliahannya?

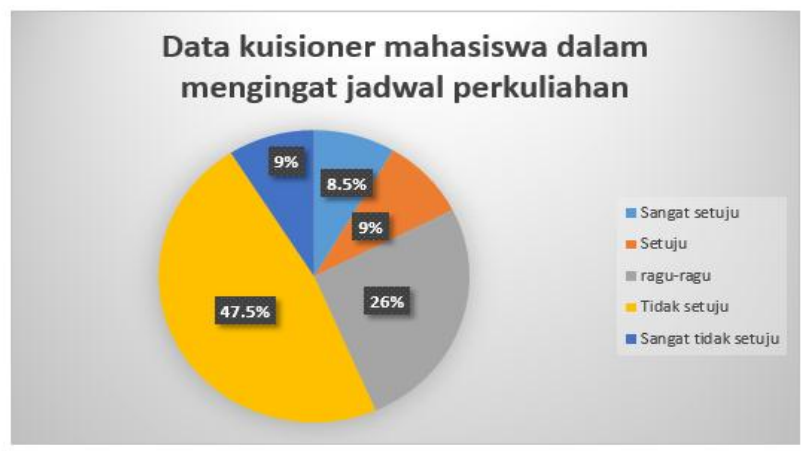

Gambar 1. Diagram Data Kuesioner Tentang Mahasiswa Mengingat Jadwal Perkuliahan. 
Dari gambar 1 menunjukan bahwa sebanyak 17 mahasiswa atau $8,5 \%$ responden menjawab sangat setuju, 18 mahasiswa atau $9 \%$ responden menjawab setuju, 52 mahasiswa atau $26 \%$ responden menjawab ragu-ragu, lalu 95 mahasiswa atau 47,5\% menjawab tidak setuju dan 18 mahasiswa atau $9 \%$ responden menjawab sangat tidak setuju. Dari hasil kuisioner tersebut didapat kesimpulan bahwa 56,5 \% atau 113 mahasiswa menyatakan bahwa mereka tidak setuju dan sangat tidak setuju mengingat jadwal perkuliahan. Untuk itu diperlukan suatu aplikasi yang dapat berguna sebagai pengingat aktifitas akademik perkuliahan.

$$
\text { Dapat diidentifikasikan }
$$

permasalahan yang ada diantaranya banyaknya mahasiswa dan dosen yang belum tahu cara menyampaikan informasi secara efektif dan efisien, belum efektifnya pengingat jadwal perkuliahan secara konvensional, kurangnya sistem informasi yang efisien bagi mahasiswa untuk merespon apabila terjadi perubahan jadwal perkuliahan, keterlambatan penyampaian informasi yang mengakibatkan banyaknya mahasiswa yang tidak mengikuti kegiatan akademik, kurangnya sosialisasi informasi membuat kurang meratanya penyebaran informasi, dan sering terjadinya penumpukkan antrian verifikasi pembayaran pada Renkeu karena banyaknya mahasiswa yang lupa dengan batas akhir pembayaran perkuliahan.

\section{TINJAUAN PUSTAKA}

Mengumpulkan data dan informasi yang diperoleh, dengan membaca dan mempelajari beberapa teori-teori, temuan dan hasil penelitian sebagai acuan untuk dijadikan landasan teori dalam kegiatan penelitian serta melakukan studi terhadap literaturliteratur berupa buku, jurnal dan informasi dari internet dan lain-lain.

\section{Observasi}

Observasi dilakukan oleh peneliti di Fakultas Teknik Universitas Bhayangkara Jakarta Raya untuk mengumpulkan data yang sesuai dengan kebutuhan penelitian. Peneliti mencari data dengan terjun langsung atau mengamati dan mencari informasi ke beberapa informan yang telah ditentukan sebagai sumber data.

\section{Kuesioner / Angket}

Dalam proses pengumpulan data tersebut penulis memberikan kuesioner kepada seluruh mahasiswa Teknik Universitas Bhayangkara Jakarta Raya sebagai populasi penelitian. Kemudian dari populasi tersebut ditentukan sampel secara acak sebanyak 200 responden dengan 5 pertanyaan dan 5 pilihan jawaban kepada mahasiswa terkait dengan masalah penelitian untuk memperoleh data yang benar dan akurat. Masing-masing jawaban memiliki bobot nilai, dimana jawaban Sangat Setuju (SS) bernilai 5, Setuju (SS) bernilai 4, Raguragu (RG) bernilai 3 Tidak Setuju (TS) bernilai 2, dan Sangat Tidak Setuju (STS) bernilai 1 . Berikut adalah pertanyaan yang di ajukan kepada mahasiswa:

\begin{tabular}{|c|c|c|c|c|c|c|}
\hline \multirow{2}{*}{ No } & \multirow{2}{*}{ Pertanyaan } & \multicolumn{5}{|c|}{ Tingkat Persetujuan } \\
\hline & & SS & ST & RG & TS & STS \\
\hline 1 & $\begin{array}{l}\text { Menurut anda, apakah smartphohe } \\
\text { adalah salah satu hal terpenting yang } \\
\text { wajib dibawa oleh mahasiswa? }\end{array}$ & & & & & \\
\hline 2 & $\begin{array}{l}\text { Menurut anda, apakah smartphohe } \\
\text { adalah salah satu hal terpenting yang } \\
\text { wajib dibawa oleh mahasiswa? }\end{array}$ & & & & & \\
\hline 3 & $\begin{array}{l}\text { Apakah mahasiswa sering telat bayar } \\
\text { kuliah akibat lupa dengan jadwal } \\
\text { pembayaran kuliah? }\end{array}$ & & & & & \\
\hline 4 & $\begin{array}{l}\text { Apakah anda pernah tahu tentang } \\
\text { aplikasi pengingat jadwal akademik } \\
\text { (E-Reminder)? }\end{array}$ & & & & & \\
\hline 5 & $\begin{array}{l}\text { Menurut pendapat anda, perlukah } \\
\text { aplikasi E-Reminder diterapkan dalam } \\
\text { lingkungan perkuliahan anda? }\end{array}$ & & & & & \\
\hline
\end{tabular}

Gambar 1. Kuisioner Untuk Mahasiswa 


\section{METODE PENELITIAN}

\section{Metode Perancangan}

Penulis membuat metode perancangan dimana tahap penelitian yang akan dilakukan ialah mengidentifitkasi adanya permasalahan yang ada pada Fakultas Teknik Universitas Bhayangkara terutama mengenai aktifitas akademik yang berkaitan tentang penjadwalan.

Menentukan pertanyaan penelitian yang akan diajukan kepada reponden terkait dengan permasalahan jadwal perkuliahan. Mendesain metode penelitian yang akan digunakan, dimulai dari mengumpulkan data hingga menganalisanya.
Mendesain Sistem E-Reminder yang akan dibuat untuk menangani permasalahan yang ada pada Fakultas Teknik Universitas Bhayangkara Jakarta Raya. Merancang menu dan submenu apa saja yang akan ditampilkan pada sistem E-Reminder tersebut. Melakukan ujicoba terhadap sistem yang telah dibuat.

Metode pengembangan sistem yang digunakan dalam pembuatan sistem $E$ Reminder ini adalah metode Rapid Application Development (RAD) kemudian melakukan perancangan desain dan antar muka menggunakan Unified Modeling Language (UML). Selanjutnya dilakukan pengujian menggunakan Black-Box Testing.

\section{Mulai}

Identifikasi Masalah

1. Banyak mahasiswa dan dosen yang belum tahu cara menyam paikan inform asi secara efektif dan efisien.

. Belum efektifnya pengingat jadwal perkuliahan secara konvensional.

3. Kurangnyasistem inform asi yang efisien bagi mahasiswa untuk m erespon apabila terjadi perubahan jadwal perkuliahan.

4. Keterlambatan penyam paian informasi yang $m$ engakibatkan banyaknya mahasiswa yang tidak mengikuti kegiatan akademik.

5. kurangnya sosialisasi informasi $m$ em buat kurang meratanya penyebaran inform asi.

6. Sering terjadinya penum pukan antrian verivikasi pem bayaran pada renkeu karena barryaknya mahasiswa yang lupa dengan batas akhir pembayaran perkuliahan.

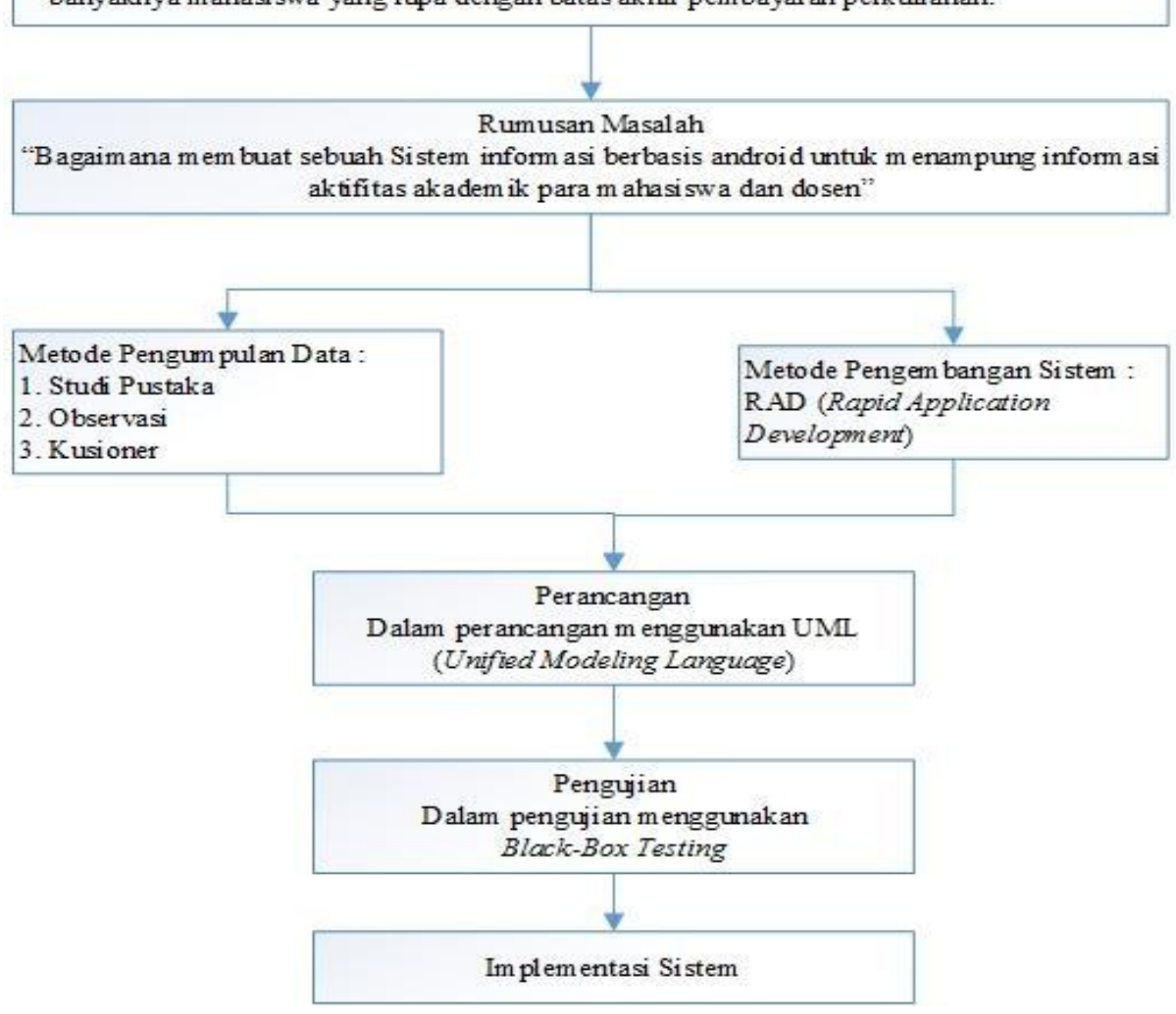

Gambar 2. Kerangka Berpikir Sistem 


\section{Analisis Sistem Berjalan}

Analisis sistem yang berjalan adalah penguraian dari suatu komponen sistem informasi yang utuh kedalam bagian-bagian komponen dengan maksud untuk mengidentifikasi dan meng-evaluasi permasalah - permasalahan dan hambatan hambatan yang sedang terjadi di lapangan dan kebutuhan yang akan dilakukan usulan perbaikan diantaranya proses mahasiswa mengingat jadwal, proses mahasiswa mengingat tahapan pembayaran kuliah, dan proses bimbingan skripsi.

\section{Analisis Permasalahan}

Dengan melihat proses sistem akademik yang sedang berjalan yang terdapat pada Fakultas Teknik Universitas Bhayangkara Jakarta Raya, sistem masih menggunakan proses secara konvensional atau tertulis yang tidak efektif dan efisien. Maka dapat disimpulkan bahwa masih terdapat permasalahan atau kekurangan dalam proses sistem yang sedang berjalan saat ini. Sebagai berikut :

- Kurangnya sistem informasi yang efisien bagi mahasiswa untuk merespon apabila terjadi perubahan jadwal perkuliahan.

- Kurangnya sosialisasi informasi mem-buat kurang meratanya penyebaran informasi Keterlambatan penyampaian informasi yang mengakibatkan ba-nyaknya mahasiswa yang tidak me-ngikuti kegiatan

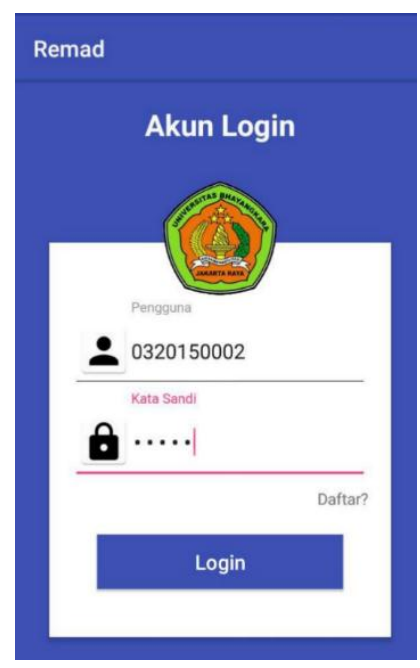

(a)

\section{Analisis Usulan Sistem}

Sistem yang diusulkan untuk menyelesaikan masalah pada sistem lama yaitu dengan membuat sistem E-Reminder aktifitas akademik. Dalam sistem tersebut data mahasiswa, jadwal perkuliahan, kalender akademik disimpan dalam sebuah database. Hal tersebut dapat mempermudah mahasiswa dalam menda-patkan reminder dari sistem yang akan dibuat.

\section{Analisis Kebutuhan Sistem}

Sebelum melakukan perancangan sistem, penulis melakukan analisis terhadap kebutuhan sistem yang bertujuan untuk menyesuaikan kebutuhan pengguna dengan aplikasi yang akan dirancang. Adapun kebutuhan sistem yang dapat disimpulkan adalah membutuhkan informasi yang akurat dan cepat dikarenakan lambat dan tidak ditampilkannya sehingga harus melihat ulang ke sistem yang lama dan membutuhkan pengingat aktifitas akademik yang dikarenakan sering terjadinya kelalaian aktifitas perkuliahan/akademik akibat human error.

\section{HASIL DAN PEMBAHASAN \\ Uji Coba Sistem}

Implementasi antarmuka akan menampilkan implementasi tampilan dari program aplikasi yang dibangun sesuai perancangannya.

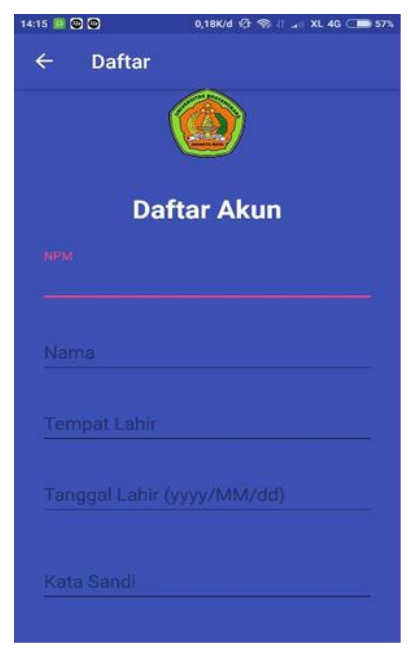

(b)

Gambar 3. (a) Tampilan Login User (Mahasiswa), (b) Tampilan daftar akun. 
Tampilan login merupakan tampilan untuk masuk kedalam perancangan aplikasi $E$ Reminder aktifitas akademik mahasiswa Fakultas Teknik Universitas Bhayangkara. Menu login pada aplikasi hanya 1 namun dibedakan dengan pengisian username, untuk user (Mahasiswa) menggunakan npm, untuk user (Dosen) menggunakan NID dan Admin menggunakan Administrator. Tampilan daftar akun merupakan tampilan untuk mendaftar akun baru sebagai user (Mahasiswa). Pada tampilan ini user (Mahasiswa) mengisi npm, nama, tempat dan tanggal lahir serta password.

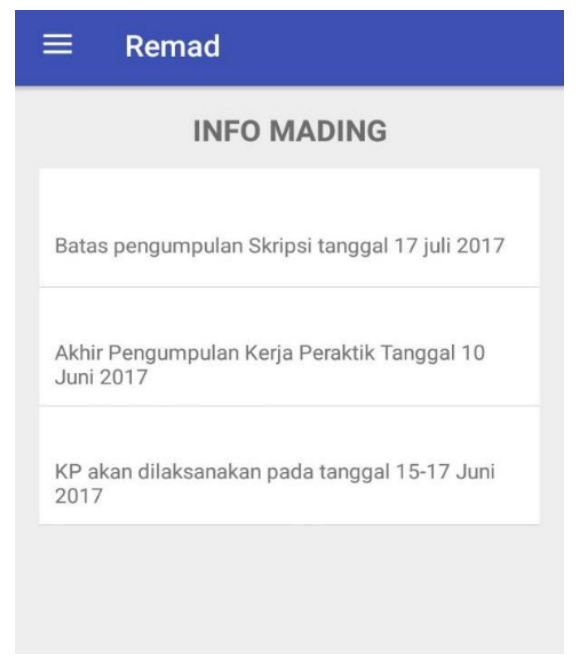

Gambar 4.Tampilan setelah Login

Tampilan setelah login user (Mahasiswa) masuk kemenu utama dimana akan muncul informasiinformasi yang berisikan pemberitahuan terkait

aktifitas akademik mahasiswa Fakultas Teknik Universitas Bhayangkara Jakarta Raya.

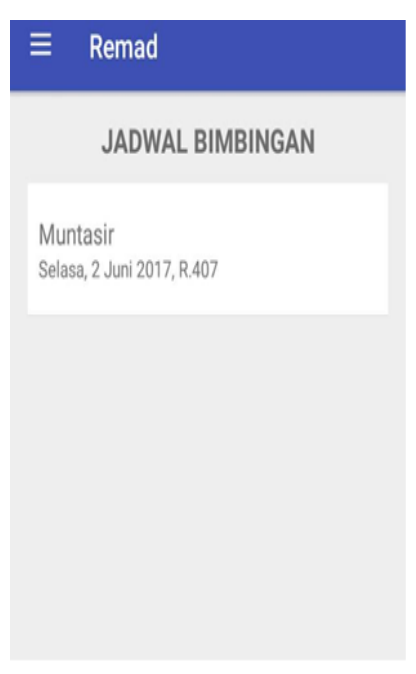

(a)

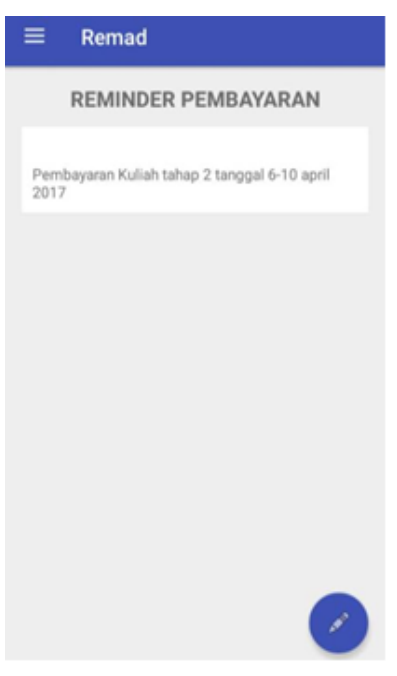

(b)

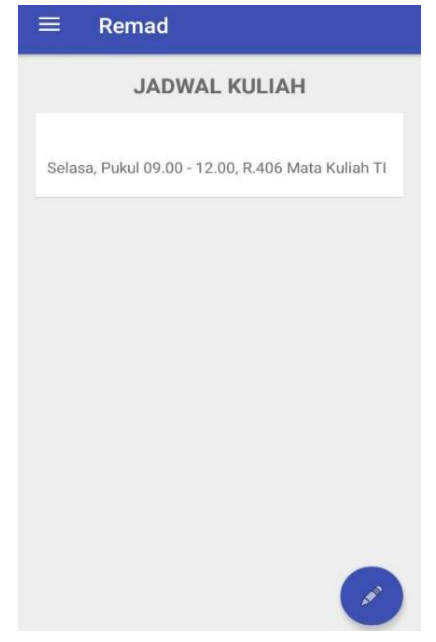

(c)

Gambar 5. (a) Tampilan reminder Jadwal Bimbingan,(b) Tampilan reminder Pembayaran Kuliah,

(c) Tampilan reminder jadwal kuliah

Tampilan jadwal kuliah merupakan tampilan bagi user (mahasiswa) apabila memilih menu jadwal kuliah. Dimana menu jadwal kuliah berisi jadwal perkuliahan yang akan dilaksanakann. User (mahasiswa) bisa update, input serta delete jadwal yang dibuat. Tampilan Jadwal Kuliah merupakan tampilan bagi user (mahasiswa) apabila memilih menu 
pembayaran kuliah. Dimana Menu pembayaran kuliah berisikan jadwal tahapan pembayaran cicilan perkuliahan yang akan dilaksanakan. User (mahasiswa) bisa menginput serta mendelete jadwal yang dibuat. Tampilan jadwal bimbingan

\section{SIMPULAN}

Aplikasi Remad dapat menjadi media pilihan baru bagi mahasiswa untuk mengakses jadwal perkuliahan dan mengurangi antrian pembayaran kuliah pada saat pengambilan kartu dikare-nakan mahasiswa lebih cepat dalam pem-bayaran kuliah.

Aplikasi yang dirancang membantu mahasiswa dalam mengetahui jadwal bimbingan langsung dari dosen pembimbing.

\section{DAFTAR PUSTAKA}

[1] Alfa Satyaputra, M. d. (2016). Let's Build Your Android Apps with Android Studio.Jakarta: Elex Media Komputindo.

[2] Annurahman. (2012). Belajar dan Pembelajaran. bandung : Alfabet.

[3] Fathansyah. (2015). Basis Data. Bandung:Informatika.

[4] Firdaus, I. J. (2015). akademik. Sistem Infromasi Akademik SMK Cendana Padang Panjang dengan menggunakan bahasa pemrograman yang berbasiskan object oriented programming, 9.

[5] Hartanto, R. P. (2015). Reminder. rancang bangun aplikasi pengingat jadwal dan tugas kuliah berbasis android, 2.

[6] Hutahaean, j. (2014). Konsep sistem informasi. Yogyakarta: cv budi utama. merupakan tampilan bagi user (mahasiswa) apabila memilih menu jadwal bimbingan. Dimana menu jadwal bimbingan berisikan jadwal bimbingan yang akan dilaksanakan user (mahasiswa), jadwal tersebut dikirimkan oleh user (dosen).

Fitur notifikasi dapat membantu mengingatkan mahasiswa akan jadwal jadwal perkuliahan, jadwal pembayaran kuliah dan jadwal bimbingan yang akan dilaksanakan. Dengan adanya aplikasi Remad dapat mempermudah penyebaran informasi dari pihak kampus.

Melalui aplikasi ini pihak kampus dapat memberikan informasi secara real- time terkait aktifitas akademik.

[7] Priyatno, d. (2012). Belajar cepat olah data statistik dengan SPSS. Yogyakarta: ANDI.

[8] Safaat, n. (2015). pemprograman aplikasi mobile smartphone dan tablet pc berbasis android. Bandung: Informatika.

[9] Salahuddin, R. A. (2014). Rekayasa Perangkat Lunak. Bandung: Informatika.

[10] Subhan, m. (2012). analisa perancangan sistem. Jakarta: Lentera ilmu cendekia.

[11] Sugiyono, P. D. (2017). Metode Penelitian Kuantitatif, Kualitatif, dan $R \& D$. Bandung: Alfabeta.

[12] Sutabri, T. (2012). Analisis Sistem Informasi. Yogyakarta: ANDI.

[13] Wahana. (2013). step by step menjadi programmer android. Yogyakarta: ANDI.

[14] Yakub. (2012). Sistem Informasi. Yogyakarta: Graha Ilmu 